\title{
Article \\ Phenolic Compounds from Leaves and Flowers of Hibiscus roseus: Potential Skin Cosmetic Applications of an Under-Investigated Species
}

\author{
Luana Beatriz dos Santos Nascimento ${ }^{1}$, Antonella Gori ${ }^{1,2, * \mathbb{D}}$, Andrea Raffaelli ${ }^{3} \mathbb{D}$, Francesco Ferrini ${ }^{1,2,4}{ }^{\mathbb{D}}$ \\ and Cecilia Brunetti ${ }^{1,2, *(1)}$
}

check for

updates

Citation: dos Santos Nascimento, L.B.; Gori, A.; Raffaelli, A.; Ferrini, F.; Brunetti, C. Phenolic Compounds from Leaves and Flowers of Hibiscus roseus: Potential Skin Cosmetic Applications of an Under-Investigated Species. Plants 2021, 10, 522. https://doi.org/ $10.3390 /$ plants10030522

Academic Editor: Dunja Šamec

Received: 19 February 2021

Accepted: 8 March 2021

Published: 10 March 2021

Publisher's Note: MDPI stays neutral with regard to jurisdictional claims in published maps and institutional affiliations.

Copyright: (c) 2021 by the authors. Licensee MDPI, Basel, Switzerland. This article is an open access article distributed under the terms and conditions of the Creative Commons Attribution (CC BY) license (https:/ / creativecommons.org/licenses/by/ $4.0 /)$.
1 Department of Agri-Food Production and Environmental Sciences (Florence), University of Florence, Sesto Fiorentino, 50019 Florence, Italy; luanabeatriz.dossantosnascimento@unifi.it (L.B.d.S.N.); francesco.ferrini@unifi.it (F.F.)

2 National Research Council of Italy, Institute for Sustainable Plant Protection (IPSP), Sesto Fiorentino, 50019 Florence, Italy

3 Institute of Life Sciences-S. Anna School of Advanced Studies, 56127 Pisa, Italy; andrea1.raffaelli@santannapisa.it

4 VALUE Laboratory on Green, Health \& Wellbeing, University of Florence, 50019 Florence, Italy

* Correspondence: antonella.gori@unifi.it (A.G.); cecilia.brunetti@ipsp.cnr.it (C.B.)

\begin{abstract}
The use of plant extracts in skin-care cosmetics is a modern trend due to their richness in polyphenols that act as anti-aging molecules. Hibiscus roseus is a perennial species naturalized in Italy, with beautiful soft pink flowers; its phenolic composition and biological activities have not been studied yet. The aim of this study was to characterize and quantify the phenolics and to evaluate the antioxidant, sun protection factor (SPF), and anti-collagenase activities of the ethanolic extracts of $H$. roseus leaves (HL) and flowers (HF). p-Coumaric, chlorogenic, and trans-ferulic acids derivatives as well as quercetin and kaempferol flavonoids were the main phenolic compounds detected. Catechin, epicatechin, kaempferol-3-O-rutinoside, kaempferol-3-O-glucoside, kaempferol-7$\mathrm{O}$-glucoside, tiliroside, oenin, and peonidin-3-O-glucoside were detected only in HF, while phloridzin was exclusive from $\mathrm{HL}$, which also showed greater amounts of hydroxycinnamic acid derivatives. $\mathrm{HF}$ was richer in flavonoids and total phenolics, also exhibiting greater antioxidant capacity. The SPF and anti-collagenase activity of both extracts were similar and comparable to those of synthetic standards. The overall results demonstrate that $H$. roseus extracts are promising sources of bioactive phenolic compounds that could be potentially applied as anti-aging agents in skin-care cosmetics.
\end{abstract}

Keywords: anti-collagenase; antioxidant; flavonoids; flowers; herbal cosmetics; hydroxycinnamic acids; LC-MS/MS-MRM; leaves; skin-care; sun protection

\section{Introduction}

The use of cosmetics is ancient, and its history shapes in parallel with that of the humankind [1,2]. Skin-care cosmetics are some of the most important products, being the major category in this industry $[1,3]$. Therefore, the interest in skin-care has become widespread, triggering the demand for effective products derived from natural sources [2].

The recent awareness about the environment, healthcare, and the minor usage of synthetic chemicals led to an increasing interest in plant-based cosmetics, which now represent one-third of the entire cosmetic sector $[1,4]$. Thus, the use of plant extracts and their phytoconstituents as active ingredients is a modern "pro-ecological" approach [5,6]. The increasing demand of these products can be due to their reduced side effects, their broad spectrum of action combined with a high efficacy, and their generally low prices [7,8].

Plants are rich in several classes of bioactive compounds, being one of the most plentiful sources of new ingredients responsible for treating many diseases $[9,10]$. In addition, plants are also sources of natural moisturizers, flavorings, and pigments, which 
make them very interesting for skin cosmetic applications [5]. Finally, plant extracts are generally considered safe and fulfill the requirements of the regulatory authorities $[10,11]$.

Among the compounds present in plant extracts, phenolics have gained special attention as active ingredients [12,13], mainly because they stand out as anti-inflammatory, antimicrobial, and antioxidant agents [14,15]. These properties make them ideal preventive and healing molecules for skin disorders, being applied in cosmetology and dermatology [16]. The noticeable antioxidant activity of phenolics is also partially responsible for their anti-aging effects, which are possibly due to their ability to reduce collagen degradation and in provide UV protection [16]. Therefore, the use of natural phenolic-rich extracts with high antioxidant capacity have been investigated and encouraged for the replacement of synthetic antioxidants in skin products [12].

Natural products extracted from plants of Malvaceae family are used worldwide, and the genus Hibiscus has gained great attention for the multiple pharmacological activities of their extracts and for their high phenolics abundance [17-19]. Hibiscus spp. contains about 240 species of annual or perennial flowering herbs, shrubs, or trees, which are distributed in different regions of the world [20]. Hibiscus extracts have been applied in traditional medicine as emollients for the treatment of many skin disorders and burns $[19,21]$. Based on these literature data, extracts from Hibiscus sp. plants might be interesting active ingredients for skin cosmetic formulations, protecting the cells from oxidative stress, collagen degradation, and against harmful effects of UV radiation.

Although the genus Hibiscus comprises many species, less than $10 \%$ of them have been investigated so far [17]. Hibiscus roseus Thore (syn. H. palustris L., H. moscheutos subsp. palustris (L.) R. T. Clausen.) is anherbaceous perennial species naturalized in Italy [22,23]. The identification and description of $H$. roseus is still under debate $[20,23]$. According to the literature, the species $H$. moscheutos subsp. palustris has been introduced very early in Europe whereas in France, it had been described as a new species, H. roseus, by Thore in 1807 [23]. This species has not been characterized for its phenolic composition and studied for its biological activities, which makes it a potential unrevealed source of bioactive compounds for skin-care products.

The folk use in skin treatments and the broad spectrum of bioactivities of Hibiscus species justify the importance of new studies focused on this plant genus [17]. Therefore, the aim of this study was to characterize the phenolic composition and to evaluate the antioxidant capacity, sun protection, and collagenase inhibition activity of the ethanolic extracts of leaves and flowers of $H$. roseus. Our results present for the first time the phenolic composition and anti-aging-related bioactivities of $H$. roseus, indicating the potential of this under-investigated species in the medicinal and cosmetic applications as an antioxidant and anti-aging additive.

\section{Results and Discussion}

\subsection{Phenolic Characterization and Quantification}

A target analysis, based on LC-MS/MS-MRM (liquid chromatography coupled with tandem mass spectrometry working in multiple reaction monitoring mode), was conducted to tentatively identify the phenolic compounds present in ethanolic extracts of $H$. roseus, since the phenolic composition of this species has not been still reported in the literature. Nineteen phenolic compounds previously described in Hibiscus genus were used as standards (Supplementary Table S1) to develop the MRM method, with the selection of the best transitions being designed by the optimization of the instrumental parameters and by literature data [24].

The main classes of compounds detected in $H$. roseus leaf and flower extracts were chlorogenic, $p$-coumaric, and trans-ferulic acids derivatives and flavonoid derivatives (Figure 1, Table 1), similarly to previous phytochemical characterization of other Hibiscus species [25-29]. Although the phenolic profile was quite similar, some qualitative differences were observed between flowers (HF) and leaves (HL) (Figure 1 and Table 1). While leaves showed richness in $p$-coumaric acid derivatives (Figure 1, blue line, peaks with Rt 
from 2 to $9 \mathrm{~min}$ ), flowers were especially rich in flavonoid derivatives such as catechins, dihydrochalcones, and anthocyanins (Figure 1, red line, Rt $>9.3 \mathrm{~min}$, Table 1).

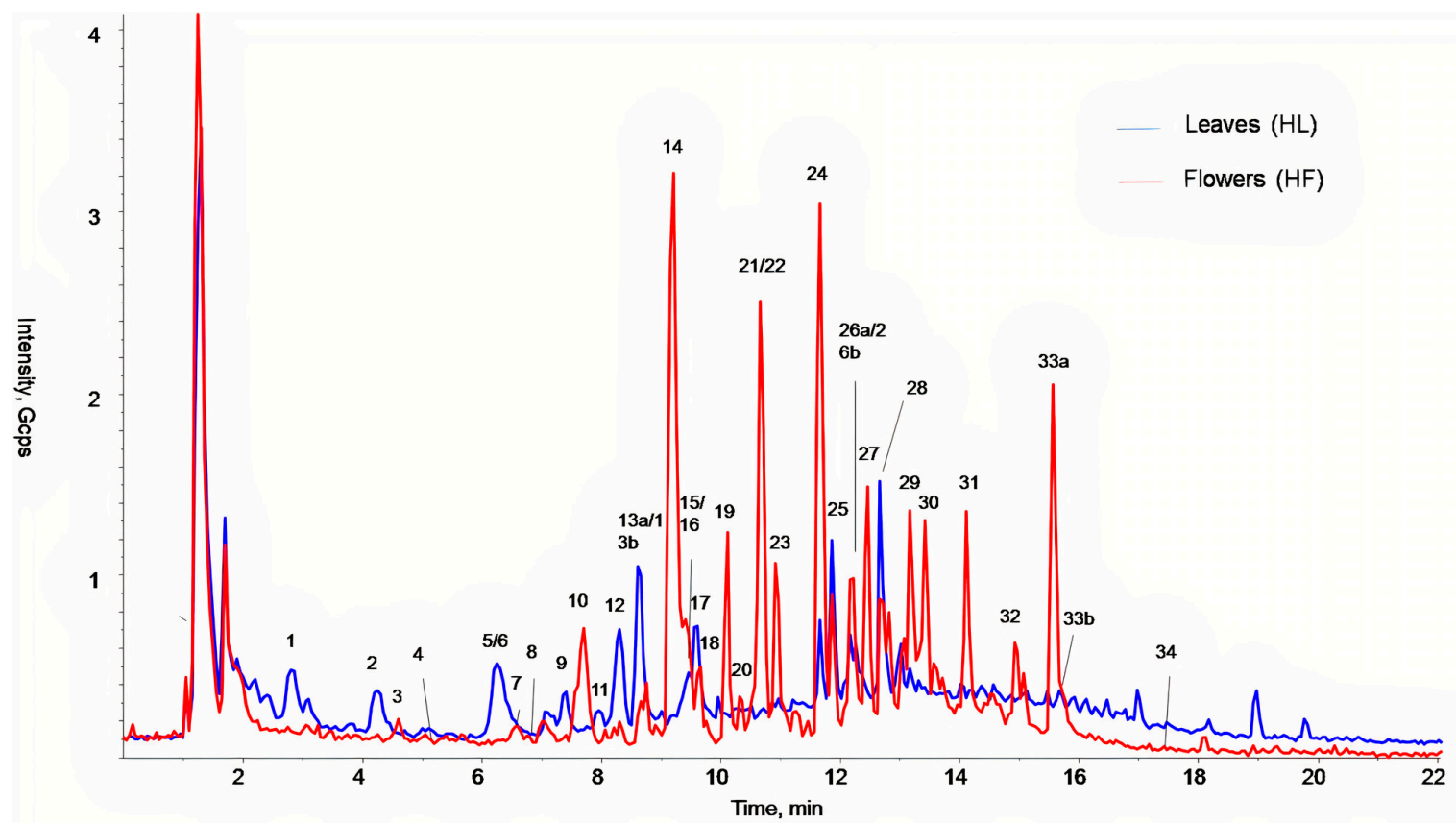

Figure 1. HPLC-MS (Scan 100-1000 Da, negative ions) chromatogram of Hibiscus roseus ethanolic extract of leaves (blue line) and flowers (red line).

Table 1. Putative identification of the main phenolic compounds found in leaf (HL) and flowers (HF) extracts of Hibiscus roseus by LC-MS/MS-MRM. Compounds numbers correspond to those indicated in Figure 1.

\begin{tabular}{|c|c|c|c|c|}
\hline Peak & $\begin{array}{l}\text { Retention Time } \\
\text { (min) }\end{array}$ & Extract & $\begin{array}{c}\text { Putative } \\
\text { Identification }\end{array}$ & $\begin{array}{c}\text { Authentic } \\
\text { Standard } \\
\text { Identification }\end{array}$ \\
\hline 1 & 2.9 & $\mathrm{HL} / \mathrm{HF}$ & $\begin{array}{c}\text { chlorogenic acid } \\
\text { derivative }\end{array}$ & No \\
\hline 2 & 4.4 & HL & $\begin{array}{c}p \text {-coumaric acid } \\
\text { derivative }\end{array}$ & No \\
\hline 3 & 4.7 & $\mathrm{HF}$ & $\begin{array}{c}p \text {-coumaric acid } \\
\text { derivative }\end{array}$ & No \\
\hline 4 & 5.7 & $\mathrm{HF}$ & $\begin{array}{c}p \text {-coumaric acid } \\
\text { derivative }\end{array}$ & No \\
\hline 5 & 6.3 & HL & $\begin{array}{c}p \text {-coumaric acid } \\
\text { derivative }\end{array}$ & No \\
\hline 6 & 6.4 & $\mathrm{HL} / \mathrm{HF}$ & $\begin{array}{c}\text { trans-ferulic acid } \\
\text { derivative }\end{array}$ & No \\
\hline 7 & 6.5 & $\mathrm{HF}$ & $\begin{array}{c}\text { chlorogenic acid } \\
\text { derivative }\end{array}$ & No \\
\hline 8 & 6.7 & $\mathrm{HF}$ & $\begin{array}{c}p \text {-coumaric acid } \\
\text { derivative }\end{array}$ & No \\
\hline 9 & 7.5 & HL & $\begin{array}{c}p \text {-coumaric acid } \\
\text { derivative }\end{array}$ & No \\
\hline 10 & 7.8 & $\mathrm{HF}$ & $\begin{array}{c}p \text {-coumaric acid } \\
\text { derivative }\end{array}$ & No \\
\hline
\end{tabular}


Table 1. Cont.

\begin{tabular}{|c|c|c|c|c|}
\hline Peak & $\begin{array}{l}\text { Retention Time } \\
\text { (min) }\end{array}$ & Extract & $\begin{array}{c}\text { Putative } \\
\text { Identification }\end{array}$ & $\begin{array}{c}\text { Authentic } \\
\text { Standard } \\
\text { Identification }\end{array}$ \\
\hline 11 & 8.0 & HL & $\begin{array}{l}\text { trans-ferulic acid } \\
\text { derivative }\end{array}$ & No \\
\hline 12 & 8.4 & HL & $\begin{array}{c}p \text {-coumaric acid } \\
\text { derivative }\end{array}$ & No \\
\hline $13 a$ & 8.7 & $\mathrm{HF} / \mathrm{HL}$ & $\begin{array}{c}p \text {-coumaric acid } \\
\text { derivative }\end{array}$ & No \\
\hline $13 b$ & 8.7 & $\mathrm{HF} / \mathrm{HL}$ & $\begin{array}{c}\text { chlorogenic acid } \\
\text { derivative }\end{array}$ & No \\
\hline 14 & 9.0 & $\mathrm{HF}$ & $\begin{array}{l}\text { trans-ferulic acid } \\
\text { derivative }\end{array}$ & No \\
\hline 15 & 9.2 & HL & $\begin{array}{c}\text { chlorogenic acid } \\
\text { derivative }\end{array}$ & No \\
\hline $16 a$ & 9.3 & $\mathrm{HF}$ & catechin & Yes \\
\hline $16 \mathrm{~b}$ & 9.3 & $\mathrm{HF}$ & $\begin{array}{l}\text { quercetin } \\
\text { derivative }\end{array}$ & No \\
\hline 17 & 9.6 & $\mathrm{HF} / \mathrm{HL}$ & $\begin{array}{c}\text { trans-ferulic acid } \\
\text { derivative }\end{array}$ & No \\
\hline 18 & 9.7 & $\mathrm{HF}$ & chlorogenic acid & Yes \\
\hline 19 & 10.3 & $\mathrm{HF}$ & $\begin{array}{c}\text { trans-ferulic acid } \\
\text { derivative }\end{array}$ & No \\
\hline 20 & 10.7 & $\mathrm{HF} / \mathrm{HL}$ & $\begin{array}{c}\text { chlorogenic acid } \\
\text { derivative }\end{array}$ & No \\
\hline 21 & 10.8 & $\mathrm{HF}$ & $\begin{array}{l}\text { peonidin-3-O- } \\
\text { glucoside }\end{array}$ & Yes \\
\hline 22 & 10.9 & $\mathrm{HF}$ & oenin & Yes \\
\hline 23 & 11.0 & $\mathrm{HF}$ & epicatechin & Yes \\
\hline 24 & 11.7 & $\mathrm{HF} / \mathrm{HL}$ & $\begin{array}{l}\text { quercetin } \\
\text { derivative }\end{array}$ & No \\
\hline 25 & 12.2 & $\mathrm{HF} / \mathrm{HL}$ & $\begin{array}{c}\text { kaempferol } \\
\text { derivative }\end{array}$ & No \\
\hline $26 a$ & 12.7 & $\mathrm{HF} / \mathrm{HL}$ & $\begin{array}{l}\text { quercetin } \\
\text { derivative }\end{array}$ & No \\
\hline $26 b$ & 12.7 & $\mathrm{HF} / \mathrm{HL}$ & rutin & Yes \\
\hline 27 & 12.8 & $\mathrm{HF}$ & trans-ferulic acid & Yes \\
\hline $28 \mathrm{a}$ & 13.2 & $\mathrm{HF} / \mathrm{HL}$ & $\begin{array}{l}\text { quercetin3-O- } \\
\text { glucoside }\end{array}$ & Yes \\
\hline $28 \mathrm{~b}$ & 13.2 & HL & $\begin{array}{l}\text { phloridzin } \\
\text { derivative }\end{array}$ & No \\
\hline 29 & 13.4 & $\mathrm{HF}$ & $\begin{array}{l}\text { quercetin } \\
\text { derivative }\end{array}$ & No \\
\hline 30 & 13.6 & $\mathrm{HF}$ & $\begin{array}{l}\text { kaempferol-3-O- } \\
\text { rutinoside }\end{array}$ & Yes \\
\hline $31 \mathrm{a}$ & 14.1 & $\mathrm{HF}$ & $\begin{array}{l}\text { phloretin } \\
\text { derivative }\end{array}$ & No \\
\hline $31 b$ & 14.1 & $\mathrm{HF}$ & $\begin{array}{l}\text { kaempferol-7-O- } \\
\text { glucoside }\end{array}$ & Yes \\
\hline
\end{tabular}


Table 1. Cont.

\begin{tabular}{ccccc}
\hline Peak & $\begin{array}{c}\text { Retention Time } \\
(\text { min) }\end{array}$ & Extract & $\begin{array}{c}\text { Putative } \\
\text { Identification }\end{array}$ & $\begin{array}{c}\text { Authentic } \\
\text { Standard } \\
\text { Identification }\end{array}$ \\
\hline 32 & 14.7 & HF & $\begin{array}{c}\text { kaempferol-3-O- } \\
\text { glucoside }\end{array}$ & Yes \\
\hline $33 a$ & 15.6 & HF & $\begin{array}{c}\text { phloretin } \\
\text { derivative }\end{array}$ & No \\
\hline $33 b$ & 15.6 & HL & phloridzin & Yes \\
\hline 34 & 17.4 & HF & tiliroside & Yes \\
\hline
\end{tabular}

Thirteen of the nineteen target phenolic compounds were authentically identified in the extracts analyzed by LC-MS/MS in the MRM mode (Table 1). The MRM is a powerful way for the simultaneous determination of several components, based on the mass-to-charge ratio $(\mathrm{m} / \mathrm{z})$ of the molecular ion $\left([\mathrm{M}-\mathrm{H}]^{-}\right)$and its corresponding daughter ion. It allows the enhancement of selectivity and sensitivity of LC-MS/MS analyses [30]. This methodology is very reliable and suitable for analyses of plant extracts and other complex mixtures leading to the highest specificity, excellent sensitivity, and an extreme multiplexing capacity thanks to the possibility of distinguishing compounds having the same parent ions but different fragments [31,32]. Using this method, we have obtained a significant reduction of chromatographic runs, a higher specificity and accuracy provided by a good separation of compounds detected with the same transitions, while avoiding a loss of sensitivity in the case of different co-eluting compounds or for compounds present in very low concentration $[24,33,34]$.

Among the 13 phenolic compounds identified utilizing authentic standards (Supplementary Table S1), ten were exclusively present in flower extracts (Figure 1 red line, Table $1 \mathrm{HF}$ ): catechin and epicatechin (peaks $16 \mathrm{~b}$ and 23), chlorogenic acid (peak 18), peonidin-3-O-glucoside and oenin (peaks 21 and 22), trans-ferulic acid (peak 27), three kaempferol glycoside derivatives (kaempferol-3-O-rutinoside, kaempferol-7-O-glucoside, and kaempferol-3-O-glucoside; peaks 30, 31b, and 32), and tiliroside (peak 34). Additionally, phloridzin (peak 33b) was detected only in leaf extracts (Figure 1 blue line, Table 1 HL), while rutin and quercetin-3-O-glucoside (peaks $26 \mathrm{~b}$ and $28 \mathrm{a}$ ) were identified in both type of extracts (Figure 1, Table $1 \mathrm{HF} / \mathrm{HL}$ ). Similar quercetin derivatives, such as quercetin-3-Osambubioside and isoquercitrin, were previously observed in $H$. sabdariffa $[26,27,29,35,36]$ and in H. rosa-sinensis extracts [18]. Some of these glycosides could correspond to the quercetin derivatives that we detected in $H$. roseus. In addition, tiliroside has been also previously detected in phenolic extracts of $H$. sabdariffa flowers [37,38]. Oenin (malvidin3-O-glucoside) and peonidin-3-O-glucoside, the two anthocyanins here identified in $H$. roseus flowers for the first time, were different from those previously described in $H$. sabdariffa flowers, delphinidin 3-sambubioside, delphinidin-3-glucoside, and cyanidin-3-Osambubioside $[27,35,39,40]$. However, it is important to mention that the most studied part of the flowers of $H$. sabdariffa is the calyx (sepals), not the petals as investigated here for H. roseus.

In addition to the compounds identified and confirmed by the authentic target standards, another 27 compounds were putatively identified in $H$. roseus leaf and flower extracts based on their MRM $(\mathrm{m} / \mathrm{z})$ and their daughter ions, thus considering the fragmentation products obtained from the precursor (Supplementary Table S1). In particular, the presence of $p$-coumaric, trans-ferulic, and chlorogenic acid derivatives, and quercetin derivatives, as well as phloretin and phloridzin derivatives were found in both extracts (Table 1).

The quantification of the phenolics identified in these extracts was performed by HPLC-DAD analysis (high-performance liquid chromatography coupled to diode array detection; Table 2). The content of hydroxycinnamic acid derivatives (THC) was higher in leaves than in flowers, while greater amounts of flavonoids (TFC) were found in flowers 
than in leaves ( $p<0.001$, Table 2). Catechin derivatives (TCD), dihydrochalcones (TDC), and anthocyanins (TAC) were quantified only in flower extracts (Table $2, p<0.001$ ). Therefore, flowers represent a greater source of phenolics compared to leaves (TPC, $p=0.002$, Table 2). Similarly to $H$. sabdariffa extracts, the major classes of compounds found in $H$. roseus leaves were chlorogenic and $p$-coumaric acid derivatives as well as caffeoylquinic and $p$-coumaroylquinic acids $[26,40,41]$. In addition, anthocyanins were exclusively reported in Hibiscus spp. flowers and calyxes, together with catechins $[19,27,28,35]$.

Table 2. Quantification of phenolics ( $\mathrm{mg} \mathrm{g}^{-1}$ dry weight, DW) in Hibiscus roseus leaf (HL) and flower (HF) extracts. TFC: total flavonoid content; THC: total hydroxycinnamic acid derivatives content; TCD: total catechin derivatives content; TDC: total dihydrochalcones content; TAC: total anthocyanins content; TPC: total phenolic content.

\begin{tabular}{ccccccc}
\hline $\begin{array}{c}\text { H. roseus } \\
\text { Extracts }\end{array}$ & THC & TFC & TCD & TDC & TAC & TPC \\
\hline Leaves (HL) & $5.08 \pm 0.48^{* * *}$ & $3.78 \pm 0.22$ & nd & nd & nd & $8.86 \pm 0.70$ \\
Flowers (HF) & $1.31 \pm 0.13$ & $6.26 \pm 0.28^{* * *}$ & $1.86 \pm 0.04 * * *$ & $2.18 \pm 0.06^{* * *}$ & $0.35 \pm 0.03^{* * *}$ & $11.96 \pm 0.48^{* *}$ \\
\hline
\end{tabular}

Results given in mean \pm SD $(n=3)$, nd: not detected by high-performance liquid chromatography coupled to diode array detection (HPLC-DAD) analysis, or because they are not present in the extracts or due to their low quantity; ${ }^{* * *} p<0.001 ;{ }^{* *} p<0.01$, comparison between flowers and leaf extracts.

By contrast, ferulic acid and its derivatives were less reported as constituents of Hibiscus spp. extracts, but they may be of great importance for their biological activities [6,42-44]. Indeed, ferulic acid derivatives obtained from different Hibiscus species showed important pharmacological properties such as antiviral and angiotensin-converting enzyme inhibitory activities $[43,44]$. In addition, ferulic acid was described as an active molecule in $H$. mutabilis, $H$. taiwanensis extracts $[45,46]$, and in $H$. sabdariffa calyx extracts $[28,38]$.

Regarding the potential cosmetic applications, it has been proven that ferulic acid inhibits melanin formation [6,42], while $p$-coumaric acid derivatives possess depigmentation $[47,48]$, anti-inflammatory, and tyrosinase inhibition activities $[47,49]$. In addition, many investigations highlight additional roles of flavonols and anthocyanins, which may act as skin protective compounds, in particular inhibiting melanogenesis [50,51] and through their action as anti-aging compounds and preventing melanoma [52,53]. In addition, the potential applications of $H$. roseus leaf extracts for skin disorders could be also enhanced by the presence of phloridzin, which has shown to decrease the expression of UVB-induced pro-inflammatory cytokines in UV-exposed skin [54].

\subsection{Antioxidant Activity Assays}

Nowadays, it is widely demonstrated that the accumulation of reactive oxygen species (ROS) is responsible for skin-aging processes, leading to dryness, losses of subcutaneous tissue, and wrinkles formation $[55,56]$. Therefore, finding natural potential antioxidant compounds that can be applied in skin-care products is very important for cosmetic industries.

Our results showed that $H$. roseus leaf extracts had lower antioxidant activity (expressed as $\mathrm{EC}_{50}$ values) than flowers (Table 3). Indeed, the antioxidant activities of flowers extracts were at least two times greater than those of the leaf extracts in both assays (Table 3). These results agree with the phenolic composition and content of these extracts (Figure 1, Tables 1 and 2), since HF extracts were richer in phenolic compounds (Table 2). Indeed, the correlation analysis between the $\mathrm{EC}_{50}$ values and the content of the different classes of phenolics showed to be significant and negative for all the compounds except for THC. As such, higher amounts of flavonoids, catechins, anthocyanins, dihydrochalcones, and total phenolic content contribute to greater antioxidant capacities (lower values of $\mathrm{EC}_{50}$ - Table 4). 
Table 3. Antioxidant activity (in terms of $\mathrm{EC}_{50}$ ) of extracts of Hibiscus roseus leaves and flowers.

\begin{tabular}{ccc}
\hline & \multicolumn{2}{c}{ EC $_{\mathbf{5 0}}$ Values $\left(\mathrm{mg} \mathrm{mL}^{-\mathbf{1}}\right)$} \\
H. roseus Extracts & DPPH Assay & HRS Assay \\
\hline Leaves (HL) & $0.38 \pm 0.05$ & $2.44 \pm 0.23$ \\
Flowers (HF) & $0.24 \pm 0.009^{* *}$ & $0.88 \pm 0.06^{* * *}$ \\
\hline
\end{tabular}

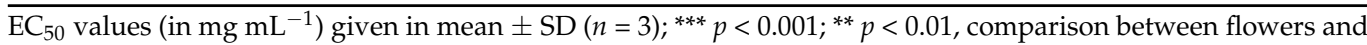
leaves extracts.

Table 4. Pearson correlation analysis between the antioxidant capacity ( $\mathrm{EC}_{50}$ values) and the phenolic content of Hibiscus roseus leaves and flowers extracts.

\begin{tabular}{ccc}
\hline Phenolic Content & $\begin{array}{c}\text { Pearson Coefficient- } r \\
\left(\text { EC }_{\mathbf{5 0}} \text { Values }\right)\end{array}$ & $p$-Value \\
\hline THC & 0.92 & $0.009^{* *}$ \\
TFC & -0.87 & $0.02^{*}$ \\
TCD & -0.92 & $0.01^{* *}$ \\
TDC & -0.91 & $0.01^{* *}$ \\
TAC & -0.92 & $0.01^{* *}$ \\
TPC & -0.94 & $0.004^{* *}$ \\
\hline
\end{tabular}

Asterisks show significant correlations among the parameters $\left({ }^{*} p \leq 0.05 ;{ }^{* *} p \leq 0.01\right)$.

Among flavonoids, quercetin and its derivatives are the most well-established antioxidant and free radical scavengers, also acting as effective inhibitors of oxidases and lipoxygenases [57]. Moreover, dihydrochalcones, such as phloretin, have also been described as potent antioxidants in 2,2-diphenyl-1-picrylhydrazyl (DPPH)-scavenging and $\mathrm{OH}$-scavenging assays [58]. In addition, anthocyanins isolated from Hibiscus extracts showed to be major antioxidant compounds in human cells [59].

Extracts of different parts of Hibiscus species have shown high antioxidant capacity $[18,21,27,35,40]$. Fractions of ethanolic extracts of $H$. sabdariffa showed very low $E_{50}$ values in antioxidant assays, which were correlated to the high content in protocatechuic acid [21,59], chlorogenic acid, flavonoids, and anthocyanins [24,60]. In addition, a study on $H$. esculentus showed the in vitro antioxidant potential of quercetin derivatives and catechins present in its extracts [61]. Finally, in H. acetosella, the antioxidant activity was strongly correlated with the anthocyanins content [62].

The results of our study on $H$. roseus ethanolic extracts showed an antioxidant activity that was a hundred times higher than those reported for aqueous extracts of $H$. sabdariffa calyx, for which the $\mathrm{EC}_{50}$ was near to $45 \mathrm{mg} \mathrm{mL}^{-1}$ in a similar DPPH in vitro model [56]. However, in distinction to our findings, the total flavonoid content and the antioxidant capacity of $H$. sabdariffa leaf extracts were higher than those of flowers [63,64].

\subsection{In Vitro Sun Protection Factor (SPF)}

Ultraviolet radiation is one of the most harmful environmental factors influencing the health and physiology of the skin, being an important extrinsic skin-aging cause $[65,66]$. Constant exposure to ultraviolet radiation increases the risk of pigmentation disorders and skin photoaging [67]. This is mostly due to the increase in ROS levels, which leads to the stimulation of collagenase production and results in considerable damage to skin cellular functions [56]. Therefore, UV-protecting ingredients, including those present in plant extracts, are widely applied in cosmetics to avoid the penetration of ultraviolet radiation in the skin but also prevent ROS production by acting as antioxidants $[56,68]$.

A simple method to verify the efficacy of different natural components as UV filters is the sun protection factor (SPF) assay, which is a rapid and reliable in vitro method based on the screening of the absorbance within UV-B spectral region (between 290 and $320 \mathrm{~nm}$ ), being useful in an early phase of selection of photoprotection active ingredients [69].

The high phenolic content and antioxidant activity of $H$. roseus extracts suggest that they may have also an UV absorbing activity. Both leaf and flower extracts of H. roseus at 
$0.1 \mathrm{mg} \mathrm{mL}^{-1}$ showed comparable SPF results $(p>0.05): 2.6 \pm 0.15$ for HL and $2.4 \pm 0.19$ for HF. These results are promising, since a standard sunscreen formulation containing $8 \%$ homosalate (a widely applied chemical sunscreen) showed an SPF value of $4[69,70]$. The results found here for $H$. roseus were similar to those found for other plant species $[68,69,71,72]$ and are important considering the low concentration of the extracts used to test this effect.

Extracts of $H$. rosa-sinensis have already shown positive effects against the ultraviolet radiation damages in mouse skin by means of antioxidant protection [73]. Natural products exhibiting SPF together with high antioxidant capacities and the inhibition of collagenase and elastase are important candidates to be used to protect the skin from photodamage and to prevent the appearance of wrinkles [66,71]. In fact, the association between approved traditional sunfilters and those derivatives of natural sources represents a trend in the cosmetic industry, since consumers perceive these products as safer, due to the side effects of synthetic UVfilters [72].

The higher content of total phenolic compounds of HF extracts (TPC; Table 2) could indicate their higher UV absorbing activity. However, both leaf and flower extracts showed very similar results, indicating that more than the total content of phenolics, the phenolic profile of the extracts would be related to the protection against UV. In particular, the higher content of hydroxycinnamic acid derivatives in HL (Table 2) may contribute to increase their SPF value, since these compounds have an UV absorption around 300-320 nm [74], which is thus centered in UV-B region. Conversely, flavonoids and anthocyanins, mostly present in flowers extracts, have a broader spectrum of absorbance in which at least two bands are present, with the major band in or near to the visible range, around $350 \mathrm{~nm}$ for flavonols and 505-550 $\mathrm{nm}$ for anthocyanins [53,69]. Indeed, hydroxycinnamic acid derivatives are produced by plants especially for their protection against UV radiation [75]. Therefore, these hydroxycinnamic acid derivatives could greatly contribute to the absorption of UV-B by human skin [6]. However, considering the presence of anthocyanins and flavonoids that cover a boarder range of wavelengths absorption, also including the UV-A and visible regions, $H$. roseus flowers extracts might be promising for further analysis and the development of sunblock cosmetic products. In addition, the higher antioxidant activity observed for HF (Table 3) could enhance the sun-protection effects in possible further formulations [69].

\subsection{Collagenase Inhibition Activity}

Both H. roseus extracts showed high collagenase inhibitory activity (>80\%) at $0.25 \mathrm{mg} \mathrm{mL}^{-1}$, which is comparable to that of the synthetic inhibitor 1,10-phenanthrolineat $1 \mathrm{M}$ (Figure 2). The $\mathrm{IC}_{50}$ value of both extracts were very similar $(p>0.05)$, $\mathrm{IC}_{50 \text { flower extracts }}=0.14 \pm 0.02 \mathrm{mg} \mathrm{mL}^{-1}$ and $\mathrm{IC}_{50 \text { leaf extracts }}=0.13 \pm 0.01 \mathrm{mg} \mathrm{mL}^{-1}$, despite their differences in phenolic composition and content (Tables 1 and 2). This could be due to the synergistic interactions between the phenolics and collagenase, which could play an important role in the inhibition mechanism. In addition, other compounds possibly present in the $H$. roseus extracts and not analyzed here might take part in the anti-collagenase activity, including vitamin $\mathrm{E}$ and ascorbic acid [71,76,77].

Moreover, the two tested standard compounds, chlorogenic acid and quercetin, whose derivatives are present in $H$. roseus leaf and flower extracts (Table 1 ), exhibited very high collagenase inhibition, with $\mathrm{IC}_{50}$ values of $5.8 \pm 0.5$ and $5.6 \pm 0.7 \mu \mathrm{g} \mathrm{mL}^{-1}$, respectively. Therefore, these compounds might be responsible for the observed anti-collagenase activity. It is relevant to notice that different classes of phenolics, which are also present in our plant extracts, have already shown anti-aging activity via the inhibition of collagen degradation and contributing to skin humidification [78]. For example, ferulic acid and its derivatives have been proven to moisturize the skin and stimulate the synthesis of collagen fibers, being used in cosmetics such as anti-wrinkle creams [6]. Furthermore, flavonols, in particular quercetin derivatives, are strong inhibitorsof the collagenase enzyme [79].

Our results show the promising effect of $H$. roseus extracts against the degradation of collagen, which is one of the greatest proteins responsible for losses in skin elasticity and integrity and in the formation of wrinkles $[80,81]$. The collagenase enzyme inhibits the 
retention of skin elasticity and tensile strength [82]. Indeed, different studies have shown the importance of natural antioxidants due to their efficacy in delaying the premature aging through the inhibition of collagenase activity $[78,83]$.

Previous studies evaluating the effects of Hibiscus species in the stimulation of collagen production and in the inhibition of collagenase activity have been conducted $[56,84,85]$. The collagenase activity inhibition of $H$. sabdariffa aqueous extracts has been recently described in literature [56]. Similar to our findings, the authors did not observe effects of collagenase inhibition at low concentrations of the extracts but only at significant high concentrations [56]. In a different study, the $\mathrm{IC}_{50}$ value in collagenase inhibition of $H$. sabdariffa ethanolic extracts was $0.75 \pm 0.04 \mathrm{mg} \mathrm{mL}^{-1}$ [65], which is an activity that is almost six times lower than those described here for $\mathrm{H}$. roseus.

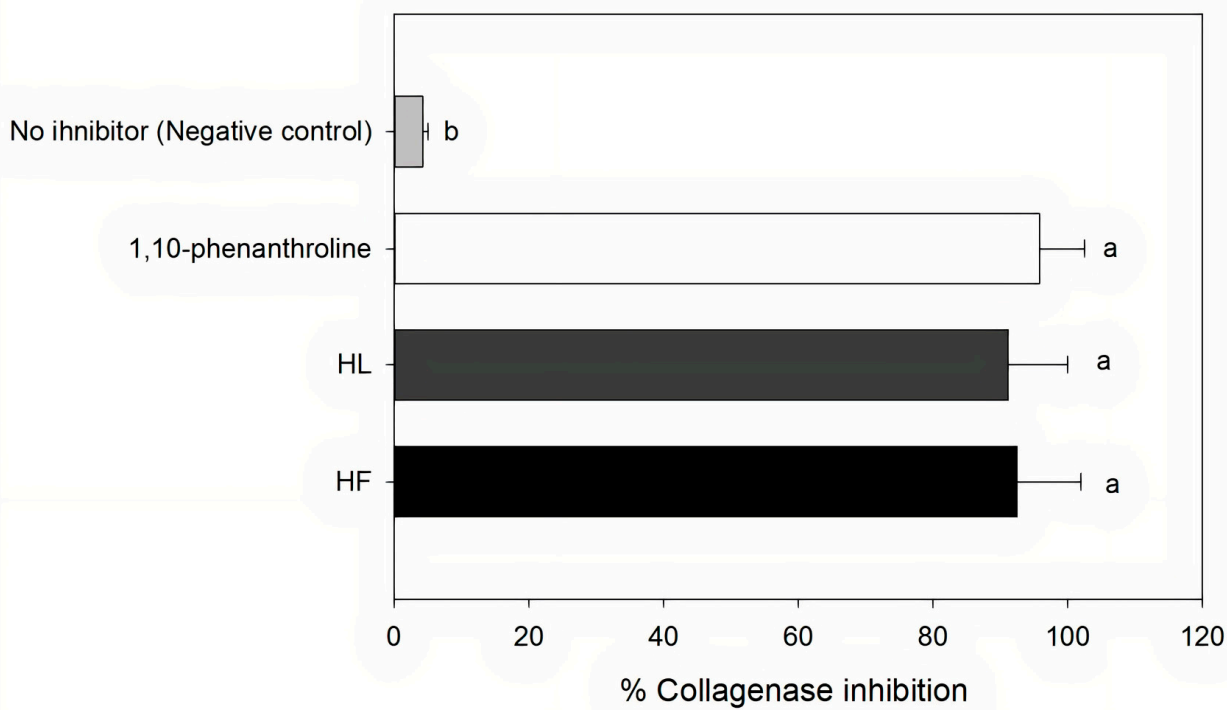

Figure 2. Collagenase inhibitory activity (in percentage) of extracts of Hibiscus roseus flowers (HF) and leaves (HL) at $0.25 \mathrm{mg} \mathrm{mL}^{-1}$, and controls (negative control-no inhibitor-and 1,10-pheanthroline $1 \mathrm{M}$ - positive control). Mean values and standard deviation $(n=3)$, different letters indicate significant differences among the samples $(p \leq 0.05)$.

\section{Materials and Methods}

\subsection{Plant Material}

Ten Hibiscus roseus Thore plants, bought from a commercial nursery in Florence (Italy), were planted in 10-liter pots filled with sandy soil (sand/peat, 60:40, $v / v$ ) and maintained in the greenhouse of the Department of Agriculture, Food, Environment and Forestry (DAGRI) - University of Florence (UNIFI), Sesto Fiorentino (Italy, $43^{\circ} 49^{\prime} \mathrm{N}, 11^{\circ} 37^{\prime} \mathrm{E}$ ). The plants were cultivated in the greenhouse from January to July 2019, under manual irrigation at the pot water capacity. From these ten different plants, two-pooled leaves and flowers were collected at the end of July during the flowering period and immediately stored at $-80{ }^{\circ} \mathrm{C}$ until the extraction.

\subsection{Ultrasound-Assisted Extraction}

Lyophilized samples (900 mg) of $H$. roseus flowers (HF) and leaves (HL) were ground in liquid nitrogen and extracted with $3 \times 15.0 \mathrm{~mL}$ ethanol 75\% (pH2.5 adjusted with $\mathrm{HCOOH}$ ) by an ultrasound-assisted extraction (UAE). The UAE was conducted in an ultrasonic bath (BioClass ${ }^{\circledR}$ CP104) using a constant frequency of $39 \mathrm{kHz}$ and an input power of $100 \mathrm{~W}$, during $30 \mathrm{~min}$, at $5{ }^{\circ} \mathrm{C}$. After centrifugation $\left(5 \mathrm{~min}, 9000 \mathrm{rpm}, 5^{\circ} \mathrm{C}\right.$; ALC ${ }^{\circledR}$ 4239R, Milan, Italy), the supernatants were partitioned with $3 \times 15 \mathrm{~mL}$ of $\mathrm{n}$-hexane to remove lipophilic compounds that could interfere with the analysis. The ethanolic phase was reduced to dryness, weighted on a digital analytical balance (Precisa ${ }^{\circledR} 125 \mathrm{~A}$ ), and the 
residue was resuspended with methanol/water acidified solution $(1: 1 v / v, \mathrm{pH} 2.5$ adjusted with $\mathrm{HCOOH})$. The extraction process was carried out in triplicate.

\subsection{LC-MS Analysis: Phenolic Profile of the Extracts}

The LC-MS analysis was conducted using an ABSciex API 3000 triple quadrupole mass spectrometer (AB Sciex LLC, Framingham, MA, USA) coupled with an Agilent 1100 HPLC system with binary pump and autosampler (Agilent Technologies, Inc., Santa Clara, CA, USA). Acquisition and data reduction were performed using Analyst 1.6.2 software (AB Sciex LLC, Framingham, MA, USA).

The HPLC separation was carried out on an Agilent Phenyl Column $(3 \times 100 \mathrm{~mm}$; $2.7 \mu \mathrm{m}$ ), and the eluents were (A) acidified water (at $\mathrm{pH} 2.5$ adjusted with $\mathrm{HCOOH}$ ) and (B) acetonitrile/water $(90 / 10$, at $\mathrm{pH} 2.5$ adjusted with $\mathrm{HCOOH})$. A gradient solvent system was used as follows: $0-3 \mathrm{~min}, 5 \% \mathrm{~B} ; 3-18 \mathrm{~min}, 5-40 \% \mathrm{~B} ; 18-28 \mathrm{~min}, 40 \% \mathrm{~B} ; 28-38 \mathrm{~min}$, $40-80 \% \mathrm{~B} ; 38-43 \mathrm{~min}, 80 \% \mathrm{~B}, 43-45 \mathrm{~min}, 80-5 \% \mathrm{~B}$, at a flow rate of $0.4 \mathrm{mLmin}^{-1}$. The MS analysis was carried out under the following experimental conditions: Atmospheric Pressure Chemical Ionization (APCI) using the heated nebulizer interface; Needle Current (NC), $-5 \mu \mathrm{A}$; Nebulizer Gas (air), 10 (arbitrary units); Auxiliary Gas (air), $3 \mathrm{~L} \mathrm{~min}^{-1}$; Auxiliary Gas Temperature (TEM), 550 ${ }^{\circ} \mathrm{C}$; Curtain Gas (CUR, nitrogen), 6 (arbitrary units); Collision Gas (CAD, Nitrogen), 9 (arbitrary units, corresponding to $2.6 \times 10^{-5}$ Torr collision cell pressure).

The identification of the different phenolic components was performed using a targeted approach, using a multiple reaction monitoring (MRM) method, optimized with standards for 19 target compounds (chosen based on previous studies of polyphenolic composition of Hibiscus spp. [25,35]): two flavan-3-ols (catechin and epicatechin), seven flavonols (quercetagetin-7-O-glucoside, rutin, quercetin-3-O-glucoside, kaempferol-3-Orutinoside, kaempferol-7-O-glucoside, kaempferol-3-O-glucoside, and quercetin), one cinnamate ester (chlorogenic acid), two hydroxycinnamic acids ( $p$-coumaric and trans-ferulic acids), two dihydrochalcones (phloridzin and phloretin), one oxyflavone (tiliroside), and four anthocyanins (myrtillin, kuromanin, peonidin-3-O-glucoside, and oenin). The retention time and the relative MRM transitions (quantifier and qualifier) were reported in the Supplementary Table S1. Moreover, additional tentative identifications have been suggested using an untargeted approach, scanning the quadrupole from $m / z 100$ to $1000 \mathrm{Da}$.

\subsection{HPLC-DAD Analysis: Quantification of Phenolics}

HPLC-DAD analysis was performed to quantify the different classes of phenolics (hydroxycinnamic acid derivatives, catechins, dihydrochalcones, flavonoids, and anthocyanins) in the extracts. Aliquots of the samples $(15 \mu \mathrm{L})$ were injected into a Perkin ${ }^{\circledR}$ Elmer Flexar liquid chromatograph equipped with a quaternary 200Q/410 pump and an LC 200 diode array detector (DAD) (all from Perkin Elmer ${ }^{\circledR}$, Bradford, CT, USA). The chromatographic conditions were the same as those used for HPLC-MS/MS analyses (Section 3.3).

The chromatograms were acquired at 280, 330, 350, and at $520 \mathrm{~nm}$ (for the quantification of anthocyanins). The identification and quantification of the phenolic compounds were carried out based on the retention time, UV spectral characteristics, and comparison with standards, as well as based on literature data $[25,35]$ and in the previous LC-MS analysis. Five-point calibration curves with different standards (chlorogenic acid, $p$-coumaric, rutin, epicatechin, naringin, and peonidin-3-O-glucoside, all from SigmaAldrich ${ }^{\circledR}-$ Merck ${ }^{\circledR} \mathrm{KGaA}$, Darmstadt, Germany) were used to quantify the different polyphenols detected and identified in the extracts. If a commercial standard was not available, the quantification was performed using the calibration curve of standards from the same phenolic class, giving an estimated content. The linearity of the curves was determined by the coefficient of determination $\left(\mathrm{R}^{2}\right)$, being higher than 0.99 for all the standards.

All the extracts were analyzed in triplicate and the quantitative results of the phenolics were given in $\mathrm{mg} \mathrm{g}^{-1}$ of dry weight ( $\mathrm{mg} \mathrm{g}^{-1} \mathrm{DW}$ ), being expressed as total hydrox- 
ycinnamic acid derivatives content (THC), total flavonoids content (TFC), total catechin derivatives content (TCD), total dihydrochalcones content (TDC), total anthocyanins content (TAC), and total phenolic content (TPC), which were estimated as the sum of the individual identified compounds belonging to each class.

\subsection{Antioxidant Activity Assays}

The antioxidant activity assay was performed using two different methods: DPPH (2,2-diphenyl-1-picrylhydrazyl) and the Hydroxyl Radical (OH)-Scavenging (HRS) assays.

The method of Khandi and Charles [86] was applied for the DPPH assay. Briefly, diluted samples of the extracts $(0.5 \mathrm{~mL})$ were added to $0.5 \mathrm{~mL}$ of DPPH solution $(0.1 \mathrm{mM}$ in methanol; Sigma-Aldrich ${ }^{\circledR}$, St. Louis, MI, USA), and the mixture was left to react at room temperature for $40 \mathrm{~min}$ in the dark. This time $(40 \mathrm{~min})$ was defined based on the kinetic analyses results of each extract and the standards chlorogenic acid and rutin. After the reaction time, the absorbance was measured at $518 \mathrm{~nm}$ using a PerkinElmer ${ }^{\circledR}$ Lambda 25UV/VIS spectrophotometer. The absorbencies of blank $(0.5 \mathrm{~mL}$ methanol and $0.5 \mathrm{~mL}$ samples) and of the negative control ( $0.5 \mathrm{~mL}$ methanol and $0.5 \mathrm{~mL}$ DPPH solution) were also evaluated. All the analyses were conducted in triplicate. The percentage of antioxidant activity was calculated as follows (1).

$$
\mathrm{AA} \%=100-\left\{\left[\left(\mathrm{ABS}_{\text {sample }}-\mathrm{ABS}_{\text {blank }}\right) \times 100\right] / \mathrm{ABS}_{\text {negative control }}\right\}
$$

The Hydroxyl Radical-Scavenging (HRS) assay was performed following the method of Smirnoff and Cumbes [87], with some modifications [88]. Different concentrations of the extracts were left to react with $\mathrm{FeSO}_{4}(1.5 \mathrm{mM})$, hydrogen peroxide $(6 \mathrm{mM})$, and sodium salicylate $(20 \mathrm{mM})$, at $37^{\circ} \mathrm{C}$ for $1 \mathrm{~h}$. Afterwards, the absorbance was measured at $562 \mathrm{~nm}$.

The $\mathrm{EC}_{50}$ values (concentration of the extract sufficient to obtain $50 \%$ of the total antioxidant activity) from both methods were calculated with the Microsoft Excel ${ }^{\circledR}$ software.

\subsection{In Vitro Sun Protection Factor (SPF) Assay}

The SPF analysis was determined according to Gaweł-Beben et al. [68] by measuring the absorbance of the extracts (at $0.1 \mathrm{mg} \mathrm{mL}^{-1}$ in methanol: water $50 \%$ ) within the wavelength range from 290 to $320 \mathrm{~nm}$, with intervals of $5 \mathrm{~nm}$ and using $50 \%(v / v)$ methanol/water solution as blank. The absorbencies were measured using a PerkinElmer ${ }^{\circledR}$ Lambda 25 UV/VIS spectrophotometer.

Equation (2) obtained by Mansur et al. [70] was applied to calculate the SPF, using the $E E \times I$ values determined by Sayre et al. [89] (Table 5).

$$
S P F=C F \times \sum_{290}^{320} E E(\lambda) \times I(\lambda) \times A b s(\lambda)
$$

where $E E(\lambda)$ - erythemal effect spectrum; $I(\lambda)$-solar intensity spectrum; $A b s(\lambda)$-absorbance of the sample; $C F$ - correction factor $(=10)$.

Table 5. Normalized product function used in the calculation of sun protection factor (SPF).

\begin{tabular}{cc}
\hline Wavelenght $(\boldsymbol{\lambda}, \mathbf{n m})$ & $\boldsymbol{E} \boldsymbol{E} \times \boldsymbol{I}$ (Normalized) \\
\hline 290 & 0.0150 \\
295 & 0.0817 \\
300 & 0.2874 \\
305 & 0.3278 \\
310 & 0.1864 \\
315 & 0.0839 \\
320 & 0.0180 \\
\hline Total & 1.0002 \\
\hline$E E$-erythremal effect spectrum, I-solar intensity spectrum.
\end{tabular}

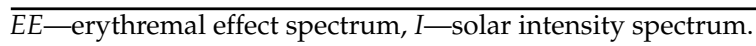




\subsection{Collagenase Activity Inhibitory Assay}

The collagenase inhibitory assay was performed similarly to those described by Roda et al. [83], using a Collagenase Activity Assay Kit (Sigma-Aldrich ${ }^{\circledR}$ ). This kit measures the collagenase activity with a synthetic peptide (i.e., FALGPA; N-(3-[2-Furyl]acryloyl)Leu-Gly-Pro-Ala) that mimics the collagen structure. According to the manufacturer instructions, aliquots $(2 \mu \mathrm{L})$ of the extracts at concentrations ranging from 0.1 to $1.0 \mathrm{mg} \mathrm{mL}^{-1}$ were spiked with collagenase $(0.35 \mathrm{U} / \mathrm{mL}, 10 \mu \mathrm{L})$ and assay buffer $(88 \mu \mathrm{L})$ in 96-well plates. An enzyme control ( $10 \mu \mathrm{L}$ of collagenase $+90 \mu \mathrm{L}$ of buffer), an inhibitor control ( $2 \mu \mathrm{L}$ of 1,10-phenanthroline $1 \mathrm{M}+10 \mu \mathrm{L}$ of collagenase $+88 \mu \mathrm{L}$ of buffer), and a blank (100 $\mu \mathrm{L}$ of buffer) were also prepared. Aliquots $(2 \mu \mathrm{L})$ of two standards (chlorogenic acid and quercetin, both from Sigma-Aldrich ${ }^{\circledR}$ ) at concentrations ranging from 0.5 to $10.0 \mu \mathrm{g} \mathrm{mL}^{-1}$ were also evaluated. The reaction was started by adding FALGPA-buffer solution to each well $(100 \mu \mathrm{L})$, and the absorbencies were immediately measured at $345 \mathrm{~nm}$ for $20 \mathrm{~min}$ for 3 min each, using a SpectraMax ${ }^{\circledR}$ reader. The reaction time was defined after a previous kinetic test. The collagenase inhibition was calculated as follows (3):

$$
\text { Collagenase activity }\left(\frac{U}{m L}\right)=\frac{\left(\frac{-\Delta A 345 n m}{\Delta T} \text { extract }-\frac{-\Delta A 345 n m}{\Delta T} \text { blank }\right) \times R V \times D F}{E C \times V}
$$

where $\Delta A_{345 \mathrm{~nm}}$ is the absorbance difference between the beginning and the end of the acquisition; $\Delta T$ is the time difference between the beginning and the end of the acquisition, $\mathrm{RV}$ is the reaction volume $(0.2 \mathrm{~mL})$; $\mathrm{DF}$ is the dilution factor; $\mathrm{EC}$ is the extinction coefficient of collagenase substrate $(0.53 \mathrm{mM})$, and $\mathrm{V}$ is the enzyme volume $(\mathrm{mL})$. All the analyses were performed in triplicate.

For both extracts (HL and HF) and for the standards, the percentage of collagenase inhibition was determined (4). Similarly to the antioxidant capacity, the results were reported as the extract concentration providing $50 \%$ of enzyme inhibitory activity (IC $C_{50}$ ).

$$
\text { Inhibition }(\%)=[(\text { Activity enzyme }- \text { Activity inhibitor }) / \text { Activity enzyme })] \times 100
$$

\subsection{Statistical Analysis}

The results of the content of phenolics, antioxidant capacities, SPF, and collagenase inhibition activity of the extracts were expressed as mean \pm standard deviation (SD) $(n=3)$. A Student'st-test was used to compare the results (flowers vs leaves samples). A correlation analysis was performed between the antioxidant activity (DPPH assay) and the respective content of classes of phenolics (HPLC-DAD quantification) using the Pearson correlation test. All the statistical analyses were performed using SigmaPlot ${ }^{\circledR}$ Systat ${ }^{\circledR}$ software (version 12.5) and the differences considered significant when $p \leq 0.05$.

\section{Conclusions}

Secondary metabolites are potential active ingredients for cosmetic new formulations. Among these, phenolic compounds extracted from plants may have great antioxidant and anti-aging properties, being effective in the inhibition of dermal enzymes (e.g., collagenase) and in UV absorption. Therefore, under-investigated plant extracts, such as those of $H$. roseus, can represent unrevealed sources of bioactive molecules.

We demonstrated that the leaves and flowers of $H$. roseus are rich in hydroxycinnamic acid derivatives and flavonoids, with flowers having greater amounts of kaempferol glycosides, catechins, dihydrochalcones, and anthocyanins, all of these compounds not described yet in the literature for this species. The great antioxidant capacity, especially of flowers extracts, together with the sun-protection and anti-collagenase activity of both leaf and flowers extracts, point out the promising utilization of this poorly investigated species in skin-care applications. In conclusion, our results showed the potential of $H$. roseus flowers and leaves as sources of phenolics as well as the activity of their extracts as anti-aging agents that might be used as ingredients for functional cosmetic products. 
Supplementary Materials: The following are available online at https: / /www.mdpi.com/2223-7 $747 / 10 / 3 / 522 / s 1$, Table S1: Retention time and transitions of the selected standards analyzed by LC-MS/MS-MRM (liquid chromatography coupled with tandem mass spectrometry working in multiple reaction monitoring mode).

Author Contributions: The authors contributed as follows: C.B.: Conceptualization, Methodology, Review and editing, Supervision. A.G.: Conceptualization, Methodology, Review and editing. L.B.d.S.N.: Conceptualization, Investigation, Data curation, Formal analysis, Software, Writingoriginal draft preparation. A.R.: LC-MS Investigation and Data curation, Review and editing. F.F.: Resources, Review and editing. All authors have read and agreed to the published version of the manuscript.

Funding: This work was supported by CNR project NUTR-AGE (FOE-2019, DSB.AD004.271).

Institutional Review Board Statement: Not applicable.

Informed Consent Statement: Not applicable.

Data Availability Statement: The data presented in this study are available on request from the corresponding author. The data are not publicly available due to the further potential uses in patents and in products development.

Acknowledgments: The authors extend their gratitude to Bianca Elena Masertifor the technical support and availability during the analysis using the SpectraMax ${ }^{\circledR}$ reader in National Research Council of Italy in Pisa. The authors thank DavinesSpA for providing fundings to carry out the research project "Attività di ricerca e sviluppo sufito complessi estratti da tessuti vegetali per utilizzo cosmetico".

Conflicts of Interest: The authors declare no conflict of interest.

\section{References}

1. Dorni, A.C.; Amalraj, A.; Gopi, S.; Varma, K.; Anjana, S.N. Novel cosmeceuticals from plants-An industry guided review. J. Appl. Res. Med. Aromat. Plants 2017, 7, 1-26. [CrossRef]

2. González-Minero, F.J.; Bravo-Díaz, L. The use of plants in skin-care products, cosmetics and fragrances: Past and present. Cosmetics 2018, 5, 50. [CrossRef]

3. Kumar, S. Exploratory analysis of global cosmetic industry: Major players, technology and market trends. Technovation 2005, 25, 1263-1272. [CrossRef]

4. Schmidt, B.M. Responsible use of medicinal plants for cosmetics. Hort. Sci. 2012, 47, 985-991. [CrossRef]

5. Aziz, A.A.; Taher, Z.M.; Muda, R.; Aziz, R. Cosmeceuticals and Natural Cosmetics. In Recent Trends in Research into Malaysian Medicinal Plants; Penerbit UTM Press: Johor, Malaysia, 2017; pp. 126-175.

6. Przybylska-Balcerek, A.; Stuper-Szablewska, K. Phenolic acids used in the cosmetics industry as natural antioxidants. Eur. J. Med. Technol. 2019, 4, 24-32.

7. Bijauliya, R.K.; Alok, S.; Kumar, M.; Chanchal, D.K.; Yadav, S. A comprehensive review on herbal cosmetics. Int. J. Pharm. Sci. Res. 2017, 8, 4930-4949. [CrossRef]

8. Mahesh, S.K.; Fathima, J.; Veena, V.G. Cosmetic potential of natural products: Industrial applications. In Natural Bio-Active Compounds; Swamy, M., Akhtar, M., Eds.; Springer: Singapore, 2019. [CrossRef]

9. Newman, D.J.; Cragg, G.M. Natural products as sources of new drugs from 1981 to 2014. J. Nat. Prod. 2016, 79, 629-661. [CrossRef]

10. Espinosa-Leal, C.A.; Garcia-Lara, S. Current methods for the discovery of new active ingredients from natural products for cosmeceutical applications. Planta Med. 2019, 85, 535-551. [CrossRef]

11. Draelos, Z.D. Cosmeceuticals: Undefined, unclassified, and unregulated. Clin. Dermatol. 2009, 27, 431-434. [CrossRef]

12. Zillich, O.V.; Schweiggert-Weisz, U.; Eisner, P.; Kerscher, M. Polyphenols as active ingredients for cosmetic products. Int. J. Cosmet Sci. 2015, 37, 455-464. [CrossRef]

13. de Lima Cherubim, D.J.; Buzanello Martins, C.V.; Oliveira Fariña, L.; da Silva de Lucca, R.A. Polyphenols as natural antioxidants in cosmetics applications. J. Cosmet. Dermatol. 2020, 19, 33-37. [CrossRef] [PubMed]

14. Ghasemzadeh, A.; Ghasemzadeh, N. Flavonoids and phenolic acids: Role and biochemical activity in plants and human. J. Med. Plants Res. 2011, 5, 6697-6703. [CrossRef]

15. Brunetti, C.; Di Ferdinando, M.; Fini, A.; Pollastri, S.; Tattini, M. Flavonoids as antioxidants and developmental regulators: Relative significance in plants and humans. Int. J. Mol. Sci. 2013, 14, 3540-3555. [CrossRef] [PubMed]

16. Faria-Silva, C.; Ascenso, A.; Costa, A.M.; Marto, J.; Carvalheiro, M.; Ribeiro, H.M.; Simões, S. Feeding the skin: A new trend in food and cosmetics convergence. Trends Food Sci. Technol. 2020, 95, 21-32. [CrossRef]

17. Maganha, E.G.; da Costa Halmenschlager, R.; Rosa, R.M.; Henriques, J.A.P.; de Paula Ramos, A.L.L.; Saffi, J. Pharmacological evidences for the extracts and secondary metabolites from plants of the genus Hibiscus. Food Chem. 2010, 118, 1-10. [CrossRef]

18. Khristi, V.; Patel, V.H. Therapeutic potential of Hibiscus rosa-sinensis: A review. Int. J. Nut. Diet. 2016, 4, 105-123. [CrossRef] 
19. Vadivel, V. Distribution of flavonoids among malvaceae family members-A review. Int. J. Green Pharm. 2016, 10. [CrossRef]

20. ThePlant List. Available online: http:/ / www.theplantlist.org/ (accessed on 15 December 2020).

21. Vasudeva, N.; Sharma, S.K. Biologically active compounds from the genus Hibiscus. Pharm. Biol. 2008, 46, 145-153. [CrossRef]

22. Fiori, A. Nuova Flora Analitica d'Italia; New York Botanical Garden: New York, NY, USA, 1923; Volume 2, p. 164. [CrossRef]

23. Winters, H.F. Our hardy Hibiscus species as ornamentals. Econ. Bot. 1970, 1, 155-164. [CrossRef]

24. Pinto, G.; Aurilia, M.; Illiano, A.; Fontanarosa, C.; Sannia, G.; Trifuoggi, M.; Amoresano, A. From untargeted metabolomics to the multiple reaction monitoring-based quantification of polyphenols in chocolates from different geographical areas. J. Mass Spectrom. 2021, 56, e4651. [CrossRef]

25. Wang, J.; Cao, X.; Jiang, H.; Qi, Y.; Chin, K.L.; Yue, Y. Antioxidant activity of leaf extracts from different Hibiscus sabdariffa accessions and simultaneous determination five major antioxidant compounds by LC-Q-TOF-MS. Molecules 2014, 19, 21226-21238. [CrossRef] [PubMed]

26. Zhen, J.; Villani, T.S.; Guo, Y.; Qi, Y.; Chin, K.; Pan, M.H.; Wu, Q. Phytochemistry, antioxidant capacity, total phenolic content and anti-inflammatory activity of Hibiscus sabdariffa leaves. Food Chem. 2016, 190, 673-680. [CrossRef]

27. Jabeur, I.; Pereira, E.; Barros, L.; Calhelha, R.C.; Soković, M.; Oliveira, M.B.P.; Ferreira, I.C. Hibiscus sabdariffa L. as a source of nutrients, bioactive compounds and colouring agents. Food Res. Int. 2017, 100, 717-723. [CrossRef]

28. Pimentel-Moral, S.; Borrás-Linares, I.; Lozano-Sánchez, J.; Arráez-Román, D.; Martínez-Férez, A.; Segura-Carretero, A. Microwaveassisted extraction for Hibiscussabdariffa bioactive compounds. J. Pharmaceut Biomed. 2018, 156, 313-322. [CrossRef] [PubMed]

29. Piovesana, A.; Rodrigues, E.; Noreña, C.P.Z. Composition analysis of carotenoids and phenolic compounds and antioxidant activity from hibiscus calyces (Hibiscussabdariffa L.) by HPLC-DAD-MS/MS. Phytochem. Anal. 2019, 30, 208-217. [CrossRef]

30. López-Fernández, O.; Domínguez, R.; Pateiro, M.; Munekata, P.E.; Rocchetti, G.; Lorenzo, J.M. Determination of polyphenols using liquid chromatography-tandem mass spectrometry technique (LC-MS/MS): A review. Antioxidants 2020, 9, 479. [CrossRef] [PubMed]

31. Olech, M.; Pietrzak, W.; Nowak, R. Characterization of free and bound phenolic acids and flavonoid aglycones in Rosa rugosa Thunb. leaves and achenes using LC-ESI-MS/MS-MRM methods. Molecules 2020, 25, 1804. [CrossRef] [PubMed]

32. Hurtado-Gaitán, E.; Sellés-Marchart, S.; Martínez-Márquez, A.; Samper-Herrero, A.; Bru-Martínez, R. A focused multiple reaction monitoring (MRM) quantitative method for bioactive grapevine stilbenes by ultra-high-performance liquid chromatography coupled to triple-quadrupole mass spectrometry (UHPLC-QqQ). Molecules 2017, 22, 418. [CrossRef]

33. Lambert, M.; Meudec, E.; Verbaere, A.; Mazerolles, G.; Wirth, J.; Masson, G.; Cheynier, V.; Sommerer, N. A high-throughput UHPLC-QqQ-MS method for polyphenol profiling in rosé wines. Molecules 2015, 20, 7890-7914. [CrossRef]

34. Olech, M.; Nowak, R.; Ivanova, D.; Tashev, A.; Boyadzhieva, S.; Kalotova, G.; Gawlik-Dziki, U. LC-ESI-MS/MS-MRM profiling of polyphenols and antioxidant activity evaluation of junipers of different origin. Appl. Sci. 2020, 10, 8921. [CrossRef]

35. Da-Costa-Rocha, I.; Bonnlaender, B.; Sievers, H.; Pischel, I.; Heinrich, M. Hibiscus sabdariffa L.—A phytochemical and pharmacological review. Food Chem. 2014, 165, 424-443. [CrossRef]

36. Lyu, J.I.; Kim, J.M.; Kim, D.G.; Kim, J.B.; Kim, S.H.; Ahn, J.W.; Kwon, S.J. Phenolic compound content of leaf extracts from different Roselle (Hibiscus sabdariffa) accessions. Plant. Breed. Biotech. 2020, 8, 1-10. [CrossRef]

37. Peng, C.H.; Chyau, C.C.; Chan, K.C.; Chan, T.H.; Wang, C.J.; Huang, C.N. Hibiscus sabdariffa polyphenolic extract inhibits hyperglycemia, hyperlipidemia, and glycation-oxidative stress while improving insulin resistance. J. Agric. Food Chem. 2011, 59, 9901-9909. [CrossRef]

38. Yang, Y.S.; Huang, C.N.; Wang, C.J.; Lee, Y.J.; Chen, M.L.; Peng, C.H. Polyphenols of Hibiscus sabdariffa improved diabetic nephropathy via regulating the pathogenic markers and kidney functions of type 2 diabetic rats. J. Func. Foods 2013, 5, 810-819. [CrossRef]

39. Escobar-Ortiz, A.; Castaño-Tostado, E.; Rocha-Guzmán, N.E.; Gallegos-Infante, J.A.; Reynoso-Camacho, R. Anthocyanins extraction from Hibiscus sabdariffa and identification of phenolic compounds associated with their stability. J. Sci. Food Agric. 2021, 101, 110-119. [CrossRef]

40. Salem, M.A.; Zayed, A.; Beshay, M.E.; Mesih, M.M.A.; Khayal, R.F.B.; George, F.A.; Ezzat, S.M. Hibiscus sabdariffa L.: Phyto constituents, nutritive, and pharmacological applications. Adv. Trad. Med. 2021,1-11. [CrossRef]

41. Formagio, A.S.; Ramos, D.D.; Vieira, M.C.; Ramalho, S.R.; Silva, M.M.; Zárate, N.A.; Carvalho, J.E. Phenolic compounds of Hibiscus sabdariffa and influence of organic residues on its antioxidant and antitumoral properties. Braz. J. Biol. 2015, 75, 69-76. [CrossRef]

42. Kumar, N.; Pruthi, V. Potential applications of ferulic acid from natural sources. Biotech. Rep. 2014, 4, 86-93. [CrossRef] [PubMed]

43. Salem, M.A.; Michel, H.E.; Ezzat, M.I.; Okba, M.M.; El-Desoky, A.M.; Mohamed, S.O.; Ezzat, S.M. Optimization of an extraction solvent for angiotensin-converting enzyme inhibitors from Hibiscus sabdariffa L. based on its UPLC-MS/MS metabolic profiling. Molecules 2020, 25, 2307. [CrossRef]

44. Takeda, Y.; Okuyama, Y.; Nakano, H.; Yaoita, Y.; Machida, K.; Ogawa, H.; Imai, K. Antiviral activities of Hibiscus sabdariffa L. tea extract against human influenza A virus rely largely on acidic $\mathrm{pH}$ but partially on a low-pH-independent mechanism. Food Environ. Virol. 2020, 12, 9-19. [CrossRef] [PubMed]

45. Saini, P.; Gayen, P.; Nayak, A.; Kumar, D.; Mukherjee, N.; Pal, B.C.; Babu, S.P.S. Effect of ferulic acid from Hibiscus mutabilis on filarial parasite Setaria cervi: Molecular and biochemical approaches. Parasitol. Int. 2012, 61, 520-531. [CrossRef] 
46. Wong, S.; Chan, E.W.; Chan, H. A review on the phytochemistry and pharmacology of two lesser-known Hibiscus species: H. taiwanensis and H. schizopetalus. Int. J. Pharmacogn. Phytochem. Res. 2016, 8, 1341-1346.

47. Song, K.; An, S.M.; Kim, M.; Koh, J.S.; Boo, Y.C. Comparison of the antimelanogenic effects of p-coumaric acid and its methyl ester and their skin permeabilities. J. Dermatol. Sci. 2011, 63, 17-22. [CrossRef] [PubMed]

48. Boo, Y.C. p-Coumaric acid as an active ingredient in cosmetics: A review focusing on its antimelanogenic effects. Antioxidants 2019, 8, 275. [CrossRef] [PubMed]

49. Varela, M.T.; Ferrarini, M.; Mercaldi, V.G.; da Silva Sufi, B.; Padovani, G.; Nazato, L.I.S.; Fernandes, J.P.S. Coumaric acid derivatives as tyrosinase inhibitors: Efficacy studies through in silico, in vitro and ex vivo approaches. Bioorg. Chem. 2020, 103, 104108. [CrossRef]

50. Jung, S.Y.; Jung, W.S.; Jung, H.K.; Lee, G.H.; Cho, J.H.; Cho, H.W.; Choi, I.Y. The mixture of different parts of Nelumbo nucifera and two bioactive components inhibited tyrosinase activity and melanogenesis. J. Cosm. Sci. 2014, 65, 377-388.

51. Riaz, A.; Rasul, A.; Hussain, G.; Zahoor, M.K.; Jabeen, F.; Subhani, Z.; Selamoglu, Z. Astragalin: A bioactive phytochemical with potential therapeutic activities. Adv. Pharmacol. Sci. 2018. [CrossRef]

52. Imran, M.; Rauf, A.; Shah, Z.A.; Saeed, F.; Imran, A.; Arshad, M.U.; Mubarak, M.S. Chemo-preventive and therapeutic effect of the dietary flavonoid kaempferol: A comprehensive review. Phytother. Res. 2019, 33, 263-275. [CrossRef]

53. Diaconeasa, Z.; Știrbu, I.; Xiao, J.; Leopold, N.; Ayvaz, Z.; Danciu, C.; Socaciu, C. Anthocyanins, vibrant color pigments, and their role in skin cancer prevention. Biomedicines 2020, 8, 336. [CrossRef]

54. Zhai, Y.; Dang, Y.; Gao, W.; Zhang, Y.; Xu, P.; Gu, J.; Ye, X. P38 and JNK signal pathways are involved in the regulation of phlorizin against UVB-induced skin damage. Exp. Dermatol. 2015, 24, 275-279. [CrossRef]

55. Rinnerthaler, M.; Bischof, J.; Streubel, M.K.; Trost, A.; Richter, K. Oxidative stress in aging human skin. Biomolecules 2015, 5, 545-589. [CrossRef]

56. Li, J.; Lu, Y.R.; Lin, I.F.; Kang, W.; Chen, H.B.; Lu, H.F.; Wang, H.M.D. Reversing UVB-induced photoaging with Hibiscus sabdariffa calyx aqueous extract. J. Sci. Food Agric. 2020, 100, 672-681. [CrossRef]

57. Dueñas, M.; Surco-Laos, F.; González-Manzano, S.; González-Paramás, A.M.; Santos-Buelga, C. Antioxidant properties of major metabolites of quercetin. Eur. Food Res. Technol. 2011, 232, 103-111. [CrossRef]

58. Li, X.; Chen, B.; Xie, H.; He, Y.; Zhong, D.; Chen, D. Antioxidant structure-activity relationship analysis of five dihydrochalcones. Molecules 2018, 23, 1162. [CrossRef]

59. Tseng, T.H.; Wang, C.J.; Kao, E.S.; Chu, H.Y. Hibiscus anthocyanins are potent antioxidants in human cells. Chem. Biol. Interact. 1996, 101, 137-145. [CrossRef]

60. Wang, C.J.; Wang, J.M.; Lin, W.L.; Chu, C.Y.; Chou, F.P.; Tseng, T.H. Protective effect of Hibiscus anthocyanins against tert-butyl hydroperoxide-induced hepatic toxicity in rats. Food Chem. Toxicol. 2000, 38, 411-416. [CrossRef]

61. Shui, G.; Peng, L.L. An improved method for the analysis of major antioxidants of Hibiscus esculentus Linn. J. Chromatogr. 2004, 1048, 17-24. [CrossRef]

62. Lyu, J.I.; Ryu, J.; Jin, C.H.; Kim, D.G.; Kim, J.M.; Seo, K.S.; Kwon, S.J. Phenolic compounds in extracts of Hibiscus acetosella (Cranberry Hibiscus) and their antioxidant and antibacterial properties. Molecules 2020, 25, 4190. [CrossRef] [PubMed]

63. Mohd-Esa, N.; Hern, F.S.; Ismail, A.; Yee, C.L. Antioxidant activity in different parts of roselle (Hibiscus sabdariffa L.) extracts and potential exploitation of the seeds. Food Chem. 2010, 122, 1055-1060. [CrossRef]

64. Chen, J.H.; Wang, C.J.; Wang, C.P.; Sheu, J.Y.; Lin, C.L.; Lin, H.H. Hibiscus sabdariffa leaf polyphenolic extract inhibits LDL oxidation and foam cell formation involving up-regulation of LXR $\alpha /$ ABCA1 pathway. Food Chem. 2013, 141, 397-406. [CrossRef]

65. Widowati, W.; Rani, A.P.; Hamzah, R.A.; Arumwardana, S.; Afifah, E.; Kusuma, H.S.W.; Amalia, A. Antioxidant and antiaging assays of Hibiscussabdariffa extract and its compounds. Nat. Prod. Sci. 2017, 23, 192-200. [CrossRef]

66. McCullough, J.L.; Kelly, K.M. Prevention and treatment of skin aging. Aging Interv Ther. 2006, 1067, 323-331. [CrossRef]

67. Narayanan, D.L.; Saladi, R.N.; Fox, J.L. Ultraviolet radiation and skin cancer. Int. J. Dermatol. 2010, 49, 978-986. [CrossRef]

68. Gaweł-Bęben, K.; Kukula-Koch, W.; Hoian, U.; Czop, M. Characterization of Cistus $\times$ incanus L. and Cistus ladanifer L. extracts as potential multifunctional antioxidant ingredients for skin protecting cosmetics. Antioxidants 2020, 9, 202. [CrossRef]

69. Radice, M.; Manfredini, S.; Ziosi, P.; Dissette, V.; Buso, P.; Fallacara, A.; Vertuani, S. Herbal extracts, lichens and biomolecules as natural photo-protection alternatives to synthetic UV filters. A systematic review. Fitoterapia 2016, 114, 144-162. [CrossRef] [PubMed]

70. Mansur, J.D.S.; Breder, M.N.R.; Mansur, M.C.D.A.; Azulay, R.D. Determinação do fator de radiação solar por espectrofotometria. An. Bras Dermatol. 1986, 61, 121-124.

71. Madan, K.; Nanda, S. In-vitro evaluation of antioxidant, anti-elastase, anti-collagenase, anti-hyaluronidase activities of safranal and determination of its sun protection factor in skin photoaging. Bioorg. Chem. 2018, 77, 159-167. [CrossRef]

72. Baldisserotto, A.; Buso, P.; Radice, M.; Dissette, V.; Lampronti, I.; Gambari, R.; Vertuani, S. Moringa oleifera leaf extracts as multifunctional ingredients for "natural and organic" sunscreens and photoprotective preparations. Molecules 2018, $23,664$. [CrossRef] [PubMed]

73. Sharma, S.; Sultana, S. Effect of Hibiscus rosa-sinensis extract on hyperproliferation and oxidative damage caused by benzoyl peroxide and ultraviolet radiations in mouse skin. Basic Clin. Pharmacol. 2004, 95, 115-220. [CrossRef] [PubMed]

74. Robbins, R.J. Phenolic acids in foods: An overview of analytical methodology. J. Agric. Food Chem. 2003, 51, 2866-2887. [CrossRef] [PubMed] 
75. Taofiq, O.; González-Paramás, A.M.; Barreiro, M.F.; Ferreira, I.C. Hydroxycinnamic acids and their derivatives: Cosmeceutical significance, challenges and future perspectives, a review. Molecules 2017, 22, 281. [CrossRef] [PubMed]

76. Bodiga, V.L.; Bodiga, S. Ascorbic acid is a potential inhibitor of collagenases-In Silico and In Vitro biological studies. In Silico Drug Design: Repurposing Techniques and Methodologies, 1st ed.; Roy, K., Ed.; Academic Press: Cambridge, MA, USA, 2019; pp. 649-677.

77. Azzi, A.; Ricciarelli, R.; Zingg, J.M. Non-antioxidant molecular functions of $\alpha$-tocopherol (vitamin E). FEBS Lett. 2002, 519, 8-10. [CrossRef]

78. Geeta, G.; Widodo, W.S.; Widowati, W.; Ginting, C.N.; Lister, I.N.E.; Armansyah, A.; Girsang, E. Comparison of antioxidant and anti-collagenase activity of genistein and epicatechin. Pharm. Sci. Res. 2019, 6, 111-117. [CrossRef]

79. Sin, B.Y.; Kim, H.P. Inhibition of collagenase by naturally-occurring flavonoids. Arch. Pharml. Res. 2005, 28, 1152-1155. [CrossRef]

80. Boran, R. Investigations of anti-aging potential of Hypericum origanifolium Willd for skincare formulations. Ind. Crops. Prod. 2018, 118, 290-295. [CrossRef]

81. Mohsen, E.; Younis, I.Y.; Farag, M.A. Metabolites profiling of Egyptian Rosa damascena Mill flowers as analyzed via ultra-highperformance liquid chromatography-mass spectrometry and solid-phase microextraction gas chromatography-mass spectrometry in relation to its anti-collagenase skin effect. Ind. Crops. Prod. 2020, 155, 112818. [CrossRef]

82. Roy, A.; Sahu, R.K.; Matlam, M.; Deshmukh, V.K.; Dwivedi, J.; Jha, A.K. In vitro techniques to assess the proficiency of skin care cosmetic formulations. Pharmacogn. Rev. 2013, 7, 97. [CrossRef] [PubMed]

83. Roda, G.; Marinello, C.; Grassi, A.; Picozzi, C.; Aldini, G.; Carini, M.; Regazzoni, L. Ripe and raw pu-erh tea: LC-MS profiling, antioxidant capacity and enzyme inhibition activities of aqueous and hydro-alcoholic extracts. Molecules 2019, 24, 473. [CrossRef] [PubMed]

84. Di Martino, O.; Tito, A.; De Lucia, A.; Cimmino, A.; Cicotti, F.; Apone, F.; Calabrò, V. Hibiscus syriacus extract from an established cell culture stimulates skin wound healing. BioMed. Res. Int. 2017. [CrossRef]

85. Yang, J.E.; Ngo, H.T.; Hwang, E.; Seo, S.A.; Park, S.W.; Yi, T.H. Dietary enzyme-treated Hibiscussyriacus L. protects skin against chronic UVB-induced photoaging via enhancement of skin hydration and collagen synthesis. Arch. Biochem. Biophys. 2019, 662, 190-200. [CrossRef]

86. Kandi, S.; Charles, A.L. Statistical comparative study between the conventional DPPH spectrophotometric and dropping DPPH analytical method without spectrophotometer: Evaluation for the advancement of antioxidant activity analysis. Food Chem. 2019, 287, 338-345. [CrossRef] [PubMed]

87. Smirnoff, N.; Cumbes, Q.J. Hydroxyl radical scavenging activity of compatible solutes. Phytochemistry 1989, 28, 1057-1060. [CrossRef]

88. Gori, A.; Tattini, M.; Centritto, M.; Ferrini, F.; Marino, G.; Mori, J.; Guidi, L.; Brunetti, C. Seasonal and daily variations in primary and secondary metabolism of three maquis shrubs unveil different adaptive responses to Mediterranean climate. Conserv. Physiol. 2019, 7. [CrossRef] [PubMed]

89. Sayre, R.M.; Agin, P.P.; Levee, G.J.; Marlowe, E. Comparison of in vivo and in vitro testing of sunscreening formulas. Photochem. Photobiol. 1979, 29, 559-566. [CrossRef] [PubMed] 